\title{
Urban Foraging: A Ubiquitous Human Practice Overlooked by Urban Planners, Policy, and Research
}

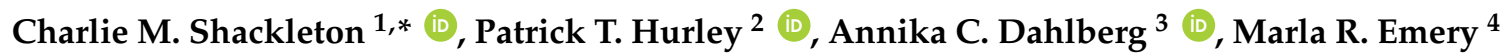 \\ and Harini Nagendra 5 \\ 1 Department of Environmental Science, Rhodes University, Grahamstown 6140, South Africa \\ 2 Department of Environmental Studies, Ursinus College, Collegeville, PA 19426, USA; phurley@ursinus.edu \\ 3 Department of Physical Geography, Stockholm University, 10691 Stockholm, Sweden; \\ annika.dahlberg@natgeo.su.se \\ 4 U.S. Department of Agriculture, Forest Service, Northern Research Station, South Burlington, VT 05405, \\ USA; memery@fs.fed.us \\ 5 School of Development, Azim Premji University, PES Institute of Technology Campus, Bengaluru, \\ Karnataka 560100, India; harini.nagendra@apu.edu.in \\ * Correspondence: c.shackleton@ru.ac.za
}

Received: 22 August 2017; Accepted: 15 October 2017; Published: 20 October 2017

\begin{abstract}
Although hardly noticed or formally recognised, urban foraging by humans probably occurs in all urban settings around the world. We draw from research in India, South Africa, Sweden, and the United States to demonstrate the ubiquity and varied nature of urban foraging in different contexts. Across these different contexts, we distil seven themes that characterise and thereby advance thinking about research and the understanding of urban foraging. We show that it is widespread and occurs across a variety of urban spaces and places. The species used and the local practices vary between contexts, and are in constant flux as urban ecological and social settings change. This requires that urban foragers are knowledgeable about diverse species, harvest locations, and rights of access, and that their practices are adaptable to changing contexts. Despite its ubiquity, most cities have some forms of regulations that prohibit or discourage urban foraging. We highlight a few important exceptions that can provide prototypes and lessons for other cities regarding supportive policy frameworks and initiatives. The formulation of dynamic policy, design, and management strategies in support of urban foraging will benefit from understanding the common characteristics of foraging in cities worldwide, but also will require comprehension of the specific and dynamic contexts in which they would be implemented.
\end{abstract}

Keywords: actors; benefits; dynamics; tenure; urban foraging; urban spaces

\section{Introduction}

Foraging by humans for wild plant, fungi and animal resources from formal and informal urban green spaces is commonplace in most modern urban centres, and has likely been throughout the establishment and growth of cities, old and new, around the world [1]. However, during the twentieth century, it became invisible to urban planners and researchers within the paradigm of the sanitary city [2], thereby masking its social, cultural, ecological, and often economic importance. However, the growing appreciation of the importance of formal and informal green spaces for urban sustainability and human well-being, has offered new perspectives and insights regarding the widespread prevalence of and practices associated with urban foraging, and potential opportunities for revising how multifunctional urban green spaces could be conceived and managed [3].

With few exceptions, the concept and practice of urban foraging is still poorly acknowledged by urban planning and management authorities and researchers [3,4]. For example, Haarland and 
Konijnendijk van den Bosch [5] do not mention urban foraging in their recent review of challenges resulting from urban densification, nor does the more recent review [6] on edible green infrastructure in cities describe or discuss foraging (although they do mention edible urban greening). Similarly, the systematic review of 174 papers by Rupprecht et al. [7] on the nature and use of informal urban green spaces mentioned urban foraging once, with two citations reporting on species used, but there was no detail on the social practices and multiple benefits of urban foraging. There is no mention of urban foraging in the extensive literature on the health benefits of urban green spaces [8,9], although it is an activity that may also have health benefits. A recent synthesis paper on the way forward in urban ecology research [10] also overlooks urban foraging. Whilst McPhearson et al. [10] stress ecosystem services throughout their paper, exemplified through the need for cities to manage climatic hazards, there is no mention of the ability of urban green areas to provide goods in the form of edible and medicinal plants. Yet, research examining the potential provisioning and cultural ecosystem services from New York City's woody species reported that 252 species, or $83 \%$ of the trees and shrubs found within the city, have at least one potential use. Since many species may be used for multiple purposes, collectively, these 252 species represented 581 distinct uses for food, medicine, or other purposes (Hurley \& Emery pers. comm.). A narrower focus on the city's street trees reveals that $78 \%$ could potentially provide edible materials, $74 \%$ medicinal materials, and $62 \%$ materials for other uses. A meta-analysis of multiple cities in the United States (US) revealed similar patterns in the widespread utilitarian values present in various urban forests [11].

The prevailing focus on a few quantifiable ecosystem services by research and planning agencies has been critiqued as being too narrow, and thus overlooking the importance of what may be termed cultural ecosystem services [12]. Based on the evidence put forward in the present paper, it is clear that research on the value of, and threats to, urban green areas would benefit by including a wider array of material goods and their linked immaterial benefits in the understanding of goods and services provided by urban plants, animals, soils, and waters. Consequently, the objective of this thought piece paper is to consolidate some of the emerging ideas and work to provide a cross-continental exposé of the practice of urban foraging, and question much received wisdom or assumptions regarding the peripheral nature of urban foraging in terms of spaces, extent, roles, and species. We do so by bringing together relatively young and emerging pictures of urban foraging across four very different settings: namely, India, South Africa, Sweden, and the US, supported with reference to other work internationally. We selected these four settings to provide what are superficially two developing and two developed countries where there is some body of literature on urban foraging. However, we argue that urban foraging is better understood at the local level, and hence national level designations are not particularly useful, except for instances where knowledge on species in common from different countries can be shared. Irrespective of national setting, the evidence that we collate shows that urban foraging may be practiced by rich and poor alike, employed and unemployed, literate and illiterate, migrants and long-term residents, with motivations and practices of individual foragers varying in time and place.

Before engaging with the case material on urban foraging, largely from the four countries, it is useful to define what we mean by the term. We regard urban foraging as the practice of harvesting or gathering raw biological resources (fungi, plants, parts of plants, invertebrate and vertebrate animals, and fish) within urban and peri-urban settings primarily for direct consumption, decoration, crafts, barter, or small-scale sale. Following Poe et al. [11], urban foraging can include wild or domesticated species in managed or unmanaged and private or public spaces. The products can be from self-reproducing plants or animals, or from those propagated directly by the harvesters or other people or agencies. Thus, at the one extreme it overlaps with urban agriculture, but at the other is entirely distinct [11]. Urban foraging provides a wide range of benefits to those who practice it (Figure 1), including improved physical and psychological health, social ties with fellow foragers, sense of place, increased ecological knowledge, stronger connections with nature, food, income or cash saving, and a source of pride [11,13]. 
It is apparent from this definition that we conceive urban foraging as a multidisciplinary subject (Figure 1), even a transdisciplinary one, if urban authorities are to design enabling policies and plans supportive of the multiple forms of urban foraging. This is necessary because much, albeit not all, urban foraging research is dichotomised between studies that either focus on resource supply, conservation, and management (i.e., what is there and used), or consider the foragers, their practices, knowledge, motivations and livelihoods (i.e., the people). These broad disciplinary fields need to be bridged for an integrated understanding and accommodation of the complexity of urban foraging as it relates to concepts, practice, and theory (Figure 1). However, a full review and analysis of disciplinary treatments of urban foraging to date is outside the scope of this paper. Scholarship on urban foraging draws on multiple concepts from social and ecological sciences, which have foundations in several social and ecological theories (such as common property, complexity, and social-ecological theory), which together have pertinence to a variety of practical domains such as urban planning, green space governance, and diversity management (Figure 1). To date, most papers on urban foraging are more empirical than theoretical, which is natural for an emerging field. Despite the applicability of a number of disciplinary theoretical and conceptual frameworks, a potentially useful overarching one is the broad framework of political ecology. This is because it addresses change over time, integrates social and natural sciences perspectives, includes a critical analysis of environmental justice, and explicitly looks at how power relations shape need, access, use, and governance responses.

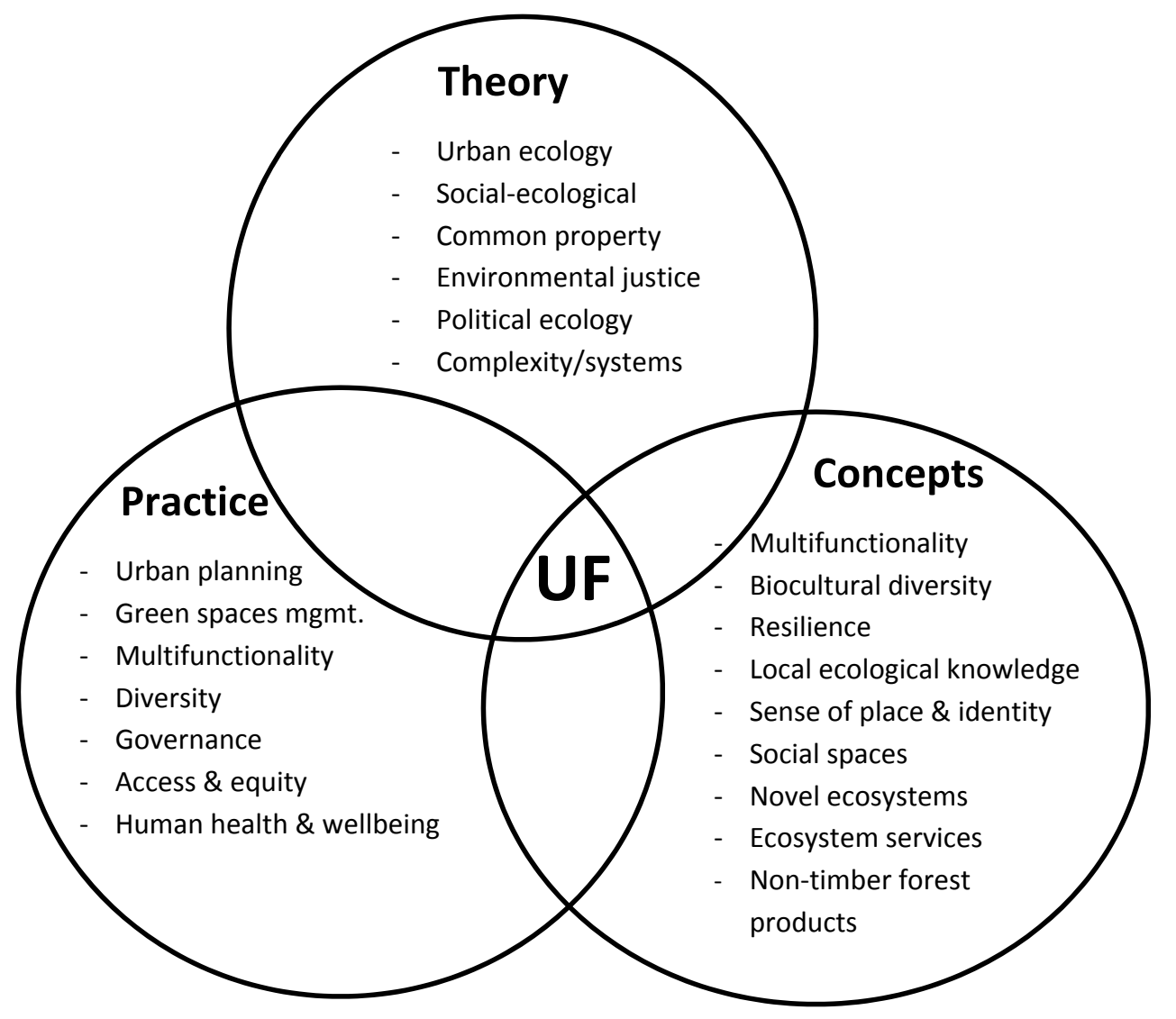

Figure 1. The multiple dimensions of urban foraging at the intersection of practice, concepts, and theory.

The development of this thought piece was an iterative process. We identified themes that could be supported by research findings from our own four countries, then added materials available from other countries, and finally considered the policy, planning, and research implications. This approach also defines the structure of the article. In the next section, we present seven themes pertaining to urban foraging that we advocate as germane to its recognition in urban research and policy debates. 
Given the multifunctionality of urban foraging (Figure 1), it is inevitable that there is some overlap between some of the themes, as the boundaries are artificial, but serve to divide the broad subject into manageable conceptual segments. The concluding section then synthesises the core planning and policy messages.

\section{Emerging Themes of Urban Foraging}

\subsection{Theme 1: Urban Foraging Is Widespread, Occurring in All Types of Towns, Cities and Countries}

Foraging is not new, in either rural or urban settings. Hunter-gatherers, past and present, obviously relied on foraging, but so did (and often do) settled farming communities, whether to supplement their own consumption or for small-scale trade [14]. The harvesting of wild resources in rural areas is relatively well known, as described for the developed world from several countries in Europe [15-17], and for the developing world in areas such as India and sub-Saharan Africa [4,18-21]. Foraging in rural areas is done by rural residents as well as people living in towns and cities, as exemplified by studies on the harvesting of berries and mushrooms in Finland [22], a variety of non-timber forest products in Scotland [23], and multiple edible species in Argentina [24], among many other examples. Some work has been conducted on the history of urban harvesting of wild and semi-wild produce, as for example, Konijnendijk's [25] research of the European context. However, as stressed by several researchers, contemporary foraging within the borders of urban and peri-urban environments receives less attention in both the developed [26] and developing worlds [4,27].

In much of the developed world for the past decades, urban green areas have been seen as and planned mainly for providing services such as recreation, shade, and stormwater management [3], and the most recent research on urban green areas has this focus [10]. However, this relatively narrow emphasis is slowly changing. There is growing recognition that a variety of urban green areas also produce goods that can be harvested, and the practices associated with doing so are important in their own right $[4,6,13]$.

Although research is lacking from many countries and regions, we suggest that urban foraging is a global phenomenon. Given the documentation of people foraging in such diverse settings as several US cities [11,13], Bangalore [19], Delhi [28], Stockholm [29], Edinburgh [23], urban and peri-urban areas in Japan [30], Uganda 45], and towns in South Africa [27,31], there is reason to believe it occurs in cities and towns hitherto not researched. In the studies referred to here, the species harvested included fungi, flowers, berries, medicinal plants, and much more. Some studies focussed on groups of species, such as fungi, whilst others include all of the species harvested by a specific group of foragers, or in a specific space. Reasons for foraging are diverse, and include, but are not limited to: subsistence needs, recreation, cultural and religious purposes, education, health, and commitments to local food security and sustainability $[4,32,33]$. These motivations can transcend global and local differences in wealth, lifestyles, cultures, and legal structures. What is clear from much of the emerging research on urban foraging and foragers is that much more research is needed in both developing and developed parts of the world.

Although many studies on urban foraging focus on species and uses, an increasing number are equally interested in foragers and their motivations and practices. Here, a multitude and diversity is revealed that unites rather than distances foragers and foraging in different countries. In the developing world, research has clearly demonstrated that poor urban communities make use of products from trees and other plants growing in or at the fringe of urban areas. Examples range from several studies in South Africa [20,31] to towns in Zimbabwe [34], Botswana [35], Tanzania and Cameroon [21]; Kampala in Uganda [4], Santa Cruz in Bolivia [36], and Bangalore in India [37]. The plants or plant parts that these studies show are commonly collected have a wide range of uses, including: berries or fruit for home consumption or sale; leaves, roots, and bark for medicines; poles for construction; and reeds for craft. However, in the developed world, urban foraging can also be a means towards improved food security, and supply other material and immaterial benefits [12]. For example, work in Seattle 
in the US has shown that far from being unimportant, harvesting in urban green areas is practiced by many and for multiple reasons [11], such as the collection of fruit and greens for food, medicinal products, and raw materials for craft work. Furthermore, civic groups promoting citizens' rights to forage in urban green spaces are in some cities beginning to have an impact on planners and the vision statements of different authorities concerned with urban green planning [26].

\subsection{Theme 2: Urban Foraging Occurs across the Full Range of Urban Landscapes and Spaces}

Urban foraging occurs in a wide range of urban landscapes, including diverse ecological spaces and cultural places. Foragers find plant materials and fungi of interest to them in city parks, institutional campuses, street tree planting areas, remnant urban woodlots, vacant lots, cemeteries, transportation and other infrastructure rights-of-way, residential yards, and allotment gardens $[11,13,38-40]$. Interviews with foragers about their typical practices have detailed the importance of having access to a wide diversity of forest, shrub, and understory plants, including wild and native species, ornamental plantings, ruderal species, and spontaneous vegetation $[4,11,26,38-40]$. These different sites and species are well documented in the US, with a range of examples, such as: foragers in Seattle sourcing edible, medicinal, and craft-related species in parks; mulberries and ginkgo berries harvested from street trees and edible mushrooms from street tree pits in New York City [39]; foragers in inner city Philadelphia locating dandelions and other greens for their use in everyday meals from cemeteries, alleyways, and neighbours' yards; and foragers in suburban Philadelphia harvesting service berries from the ornamental plantings of new housing developments and around public buildings [39]. In Syracuse, New York in the US, an immigrant group whose urban garden was vandalised and crops destroyed foraged "weeds" from nearby vacant lots, thereby ensuring their families were able to meet critical short-term food needs. In New Zealand, interviews with Maori elders revealed that fragmented lands in urban areas provided access to important medicinal plants [41].

Urban foraging research in the developing world is revealing the complex ways that residents use urban spaces to secure food, medicines, and other material resources. Research from South Africa highlights the importance of trees for the provision of foods, medicines, and materials, including the harvest of items from homestead trees planted for other purposes [42]. This includes fruit trees planted on personal lands and those of friends or relatives, while wild fruits were collected on commons in the peri-urban areas of towns. In some cases, foraged fruits from diverse urban spaces supplemented other harvests and purchases [20], whereas wooded urban and peri-urban areas were a source of poles for building construction [20,27]. In Bangalore (India), local lake beds provide nutritionally rich greens, and urban woodlots offer access to key fruits. Foraging in slums provides access to food and medicine from herbaceous plants, vines, shrubs, and trees that likely grew as spontaneous vegetation, with more than $25 \%$ of the species encountered in alleyways used by residents for food or other culinary uses [40].

Publicly owned and managed lands appear to be particularly important to foragers. In the US, for example, parks in New York City, Philadelphia, and Seattle are among the most frequently mentioned foraging sites [39]. This includes large, iconic parks, as well as small neighbourhood greenspaces. More than $75 \%$ of documented foraging in Philadelphia takes place in parks, with several species reportedly harvested only in parks. A survey of landowners in cities and suburbs located in eastern Massachusetts indicated harvests on nearby conservation lands [43]. Research in Stockholm documents mushroom foraging in that city [29], and the harvesting of berries (such as lingonberries and blueberries) is very common, with other fruits, berries, and greens also widely observed, but less common (Dahlberg pers. obs). In Berlin, the most frequently observed activity amongst visitors to two parks was foraging, which encompassed 15 different species for food, teas, medicinal herbs, and pet foods [44].

Public lands also function as de facto commons in developing countries, and are important in providing access to species sought out by foragers. In South Africa, public spaces provided access to fruits for residents from informal settlements [42]. Further, research from smaller cities in South Africa 
show that these public commonages provided access to other edible species, as well as medicines and building materials [20,27,31]. As mentioned above, the urban woodlots and lakes of Bangalore function as resource commons for foragers, as do the alleyways and other informal spaces of urban slums [40].

Public lands, such as parks, are also important for additional reasons. Interviews with foragers in Philadelphia and New York City suggest that parks facilitate group-oriented foraging practices and associated learning through organised group educational hikes [39]. Foraging tours have become a regular, if unauthorised, feature in several New York City parks, with individuals who have written field guides or developed other educational materials leading guided walks of edible and useful species. Recreational trails through suburban areas may also feature urban foraging opportunities, spaces, and species [39].

\subsection{Theme 3: The Nature of Urban Foraging Takes Many Forms in Terms of Actors, Frequencies, Dependencies,} Products Collected, Reasons, and Benefits

Diversity, multifunctionality, and adaptability to dynamic contexts are hallmarks of urban foragers and foraging (Figure 1). The practices of seeking, harvesting, preparing, and consuming foraged plant materials and fungi transcend social boundaries of all kinds [13,45]. In cities all around the world, people who forage include the comparatively affluent and those with scarce financial resources [4,13,20,27,39], different genders [13,37], and those from varied cultural backgrounds [13,29,39]. The length of residence in the city may affect foraging behaviour, where an individual forager may fall anywhere on a temporal continuum from episodic and recent to permanent and multigenerational. Thus, some urban foragers are intra- and international migrants recently settled in the city, while others are nomadic peoples whose annual cycle of movement includes time spent in the city [37], and still others are long-term or lifetime residents $[21,37,46]$. In many cities, children and adolescents are active participants in foraging activities, either in peer groups foraging together or with adults, and they may also be targeted as students by urban ecology or urban agricultural and food growing programmes in formal educational institutions.

Regardless of time or place, urban foragers must adapt their practices to the intensively dynamic social and ecological environments of cities. The novel ecological assemblages of urban environments [47] include native and non-native species in often shifting spatial distributions as the development of the built environment and management of designated greenspaces creates conditions for some plant and fungal species to flourish, and others to become less abundant or locally eradicated. These ecological dynamics are affected by social processes, along with the direct and indirect effects of climate change on species prevalence and abundance [48]. In addition to the conversion of greenspace to hardscape [21,32], remaining greenspaces may be privatised or reconceptualised as spaces for non-consumptive recreation and nature watching, resulting in the closure of de facto commons where foraging previously occurred unhindered [49,50]. Clark and Nicholas [51] surveyed 30 urban forestry master plans from North America and found an underlying prioritisation of wildlife habitat over food security that shapes urban forest planning in most cities.

As indicated in the previous sections, the reasons urban foragers engage in the practice are not mutually exclusive, and indeed, a multifunctionality of reasons, species, and spaces is at the heart of urban foraging's value [52]. At any given time, individuals and communities of foragers may obtain multiple benefits from foraging in urban environments, including resources for self-provision, sale to provide supplemental income, ceremonial or spiritual observations, and a sense of peace and well-being. In addition to this multifunctionality, at any one time, the relative magnitude and importance of values also may change over individuals' and households' lifetimes [21,42] in response to factors such as natural disasters and armed conflict [53]. Understanding the dynamics of urban foraging's values in relation to household livelihoods and external contexts is a fruitful area for future research. 


\subsection{Theme 4: There Is a Continuum of Dependency on Urban Foraging}

Urban foraging can encompass a range of situations, from occasional recreational or cultural use, to subsistence use to fulfil basic needs with important health and nutritional dimensions, to harvesting for processing and sale for livelihood supplementation. In all cases, urban foraging contributes important and even essential aspects of urban well-being.

Some urban foragers contribute value-additions to the products they extract, and transform the products into items for sale. In Charleston, South Carolina, African American communities draw on their cultural heritage to collect sweetgrass (Muhlenbergia sericea), longleaf pine needles (Pinus palustris), black rush cuttings (Juncus roemerianus), and palmetto fronds (Sabal palmetto); which are combined to make baskets, which contribute significantly to household and local economies in this region, as well as maintain biocultural knowledge [32]. At the other end of the spectrum are contexts such as that of Lake Arrie in southern Sweden, where there is an active angling club comprised of local residents that engage in fishing for recreation and personal consumption [54]. Similar examples for other products are easy to identify, such as the harvest of morel mushrooms (Morchella spp.) and ginseng (Panax quinquefolius) in southern Indiana (US) for medicinal purposes [55], and a range of different mushroom species collected by first and second generation Polish immigrants to Stockholm as a central ingredient for traditional dishes [29]. Whilst these products are not the basis for household food security, they play an important cultural role, as they contribute to a sense of place and urban social capital.

Urban agriculture provides perhaps the best-known example of urban foraging, and has been acknowledged in a number of global policy documents for its contribution to increase the resilience of cities to shocks of various kinds. For example, Clark and Nicholas [51] identified 37 urban community initiatives focussed on food tree plantations in Europe and North America. Several of these focussed explicitly on plantations and harvest in low-income neighbourhoods, and demonstrated the importance of plantations for urban foraging to address issues of urban food insecurity and malnutrition. In cities that have dealt with a large influx of migrants from different cultural backgrounds, people from diverse geographic origins have brought in plants from their own country and context, which has increased the biodiversity and cultural diversity of cities such as Malmö in Sweden [56]. Recent migrants in peri-urban areas seem to depend more on the harvest of wild natural resources available in open areas or urban commons, while older residents in long settled parts of cities seem to invest more in urban agriculture and a greater use of private spaces to which they may have established networks and rights of access. This is most likely a function of the higher "wild" ecosystem resource availability in peri-urban areas, as well as the increased tenure security of long-term residents in older urban settlements [21], and policy interventions such as the privatisation of urban commons in some cities [37]. The increasing greening of rooftops presents novel opportunities and great potential for urban agriculture [6].

\subsection{Theme 5: Urban Expansion and Transformation Continually Reshape Foraging Spaces}

Foraging is not limited to immediate urban areas, or those spaces regularly associated with the interior of cities; it also, and in some places predominantly, takes place in suburban and peri-urban areas $[21,29,39,40,43,45,57,58]$. Across this urban spectrum, patterns of foraging appear to share many similarities, and foragers living in the city or suburbs are often engaged in foraging in areas both inside and outside the city. What spaces are considered city, suburb, and peri-urban areas is also rapidly changing. Sprawling suburbs experiencing densification have laid claims to being city-centres in their own right, and many formerly rural areas in both the developed and developing world can now be described as peri-urban $[59,60]$. At the same time, formal and informal green spaces within existing city boundaries are transformed by urban development. These urbanisation patterns reconfigure the location, size, distribution, nature, management of, and access to the ecologies and green spaces that support actual or potential foraging [21,32,39,40]. The current state of knowledge about these dynamics, as well as other aspects of foraging referred to in this paper, is generally lacking. However, 
research from the US, southern Africa, Sweden, and India (including those studies highlighted above) suggest important similarities and differences in the ways that urbanisation may influence foragers and foraging. Research on the status of non-timber forest products (NTFPs) in rural areas experiencing diverse types of urbanisation is generally lacking. A major exception is the work on sweetgrass basketry among African Americans living in the South Lowcountry [61]. This work highlights similarities in the situation of rural NTFP users with regard to stable NTFP supplies in other areas of the country [52], including the extent to which changing patterns of land tenure, ownership, and management play in shaping access to key NTFPs. This emerging research suggests that changes in ownership patterns, land use, and land management strategies represent both challenges to, and opportunities for, the continuation of foraging practices in urbanising areas [21,32,39,40,52,62,63].

That urban and peri-urban green areas are integral to urbanisation processes is illustrated by research from South Africa, where foraging for personal consumption as well as for providing additional income is of particular importance among recent migrants from the countryside to urban areas [20]. The work of Petersen et al. [64] from Cape Town illustrates the extent to which rural-to-urban migrants forage in parts of the urban periphery, collecting 250 species of plants. However, the development processes that accompany urbanisation may negatively affect both recent migrants and established residents. In Bangalore, India, lakes and woodlots in the sites of expanding cities that have been historically treated as public commons are being transformed into both private lands and public lands managed as parks [40]. In the process, perceptions about the appropriate uses of these spaces and their plants are changing, with management strategies commonly prioritising aesthetics and recreation over provisioning uses. Fences, security guards, and regular patrols, as well as changes in landscaping design in some cases, accompany these shifts in management priorities. This often results in lost access for foragers, as well as a potential change in species diversity that may reduce the number of usable species. Moreover, the ecological degradation of habitats may result from the biophysical processes often associated with urban expansion, such as increases of sewage in lakes, the conversion of lakes and woodlots to housing, and road expansions removing street trees [65].

\subsection{Theme 6: The Constant Reconfiguration of Urban Green Spaces Requires Adaptability and Mobility for the Actors Involved}

As previously described, urban landscapes, or citiscapes, are dynamic as cities expand and also internally reconfigure land uses and landscape characteristics through time. These changes may be largely planned and managed, such as via industrialisation and densification; unanticipated by urban authorities and hence initially unmanaged, such as land invasions and waste dumping; or may be the effect of both, such as in the case of gentrification. A reconfiguration of spaces results in changes in land uses, access, and available species, to which urban foragers need to adapt. New spaces and new sources of popular resources will become available, but the opposite will also occur, in that established spaces and resources disappear or become unavailable to the public. This necessitates that foragers are adaptive, innovative, and knowledgeable about alternative sites, species, and uses. Thus, foragers need to be conscious and knowledgeable of the changing landscapes around them. We can hypothesise that longer-term residents will have greater knowledge of spaces compared with new urban migrants, who need time to accumulate the knowledge and experience of available foraging areas, and the formal or informal rules of access and use. However, this assumption does not always hold true, which illustrates how dynamic foraging is, and that one should be cautious in using the concept of "traditional" when trying to understand practices and change. Schlesinger et al.'s [21] study of six African cities found no difference between long-term residents and more recently urbanised ones in the prevalence of use of a variety of locally procured resources such as firewood, wild fruit, or medicinal plants. Similarly, Edelman [29] found that in Stockholm, urban foraging for mushrooms was equally high, if not higher, in terms of species harvested, amounts, and in knowledge about how to prepare and preserve them, amongst first and second generation migrants from Eastern European countries compared with resident Swedes. 
The adaptability to changes in the location and abundance of, as well as access to, required resources was evident in the case of sweetgrass resources in coastal South Carolina in the US [39,62]. First was the change in locations and the abundance of sweetgrass as harvesting areas were built upon. Second was the change in access to sites, as formally public lands became privatised. The former required that harvesters locate new harvesting sites, which usually meant they had to travel further afield. The latter required that they evolve new social networks and negotiate new rules pertaining to access rights.

More pervasive lifestyle and livelihood changes in the face of inexorable urbanisation are depicted by communities living adjacent to an urban lake in Bengaluru, India [66,67]. What used to be agro-pastoralist, rural communities were enveloped by the expanding city. Through the ensuing decades, the location and abundance of key resources such as land, fodder for livestock, and fish were in constant flux as spaces were claimed or abandoned for different purposes, including building developments. At times, resource supply or access constraints undermined the very existence of some households, resulting in out-migration or a total change in livelihood occupations. The need for constant adaptation can at times result in conflicts between foraging and other types of use of urban ecosystems. For instance, during the transformation of Bangalore's lakes, fishers came into conflict with urban naturalists, who felt that the harvest of fish decreased the fish stock in the lake, and negatively impacted bird populations [49].

\subsection{Theme 7: Most Cities Authorities Currently Frame Urban Foraging as an Illegal or Undesirable Activity}

The regulation and governance of urban foraging in different countries and towns has not been well explored. Whilst we are aware of a range of systems across specific settings, it is most common for municipal regulations to have either no explicit mention of foraging, or some form of restriction or prohibition applied to public or common lands. Private lands are usually exempt from such formal harvesting-related restrictions, although "standard" trespass laws often apply, which demand that foragers obtain permission from the landowner to access private sites. However, as with many aspects of urban foraging, the picture of any given town or city is not always clear, not least because of the multiple levels of government that purportedly have some jurisdiction. These levels include local municipal authorities, up to country, state, and even national levels, as well as the different agencies that may deal with separate but often overlapping interests (such as conservation, parks, agriculture, land use planning, environment, health, and safety) and thus often have divergent and sometimes contradictory goals.

McLain et al. [26] surmise that in the US, foraging is largely a prohibited activity on public lands in cities and suburbs. Interviews with park managers suggested that urban foraging was seen as a largely unwanted activity from a policy perspective as it "damages" park resources, although some managers recognise the benefits of environmental awareness and ecological knowledge that can come from such more direct interactions with the landscapes and flora in the parks. An exception was Seattle, where policymakers recently embraced some aspects of foraging, including a revision of the policy language in the city's urban forest stewardship plan, and efforts are underway to develop a new food forest for foragers [26]. In Stockholm (Sweden), a brief survey among some of the officials in charge of the management of the urban parks revealed a surprising lack of certainty in terms of what was allowed or not [Dahlberg pers. comm.]. In rural areas, the Swedish right of public access [68] makes it quite clear what can be harvested and not, but how this regulatory policy should be applied in cities has not been explored. Some managers participating in the survey were positive towards the foraging of fruit in public places, and one had organised the planting of apple and cherry trees for this purpose. However, at the same time, others referred to official statements that prohibited any harvesting from planted vegetation, as well as any wild vegetation such as flowers growing on planned urban land. Around the world, it is not an uncommon sight in parks to see signboards prohibiting picking or foraging.

The situation regarding foraging from more informal public lands, such as servitudes and undeveloped or remnant lands and derelict private lands is even less clear. Many such areas are 
not actively managed or regulated, and hence city authorities have no or only limited knowledge of the activities taking place in these types of spaces. This uncertainty, however, makes foragers vulnerable to arbitrarily imposed restrictions (such as evictions of urban cultivators) that may lack any real regulatory basis.

It is likely that the regulations pertaining to foraging on private lands will be clearer if the owner of the land occupies it, or is frequently seen on the land to oversee any agreed harvesting or access rights. However, private lands that appear to be un- or little used, and thus take on a visage of abandonment, may become harvesting sites for neighbours or foragers from further afield. This has the potential for conflict when there is no uniform understanding of who owns or is responsible for specific parcels of land, or where private property owners occupy or claim jurisdiction over neighbouring public lands or rights of way, such as bulrush harvesters being harassed by landowners for their harvests in tidal wetlands that are in publicly owned areas, but are often perceived of as private property by adjacent residents [32,39].

The acceptance of foraging on lands on the urban periphery is equally complex, and depends upon who owns the land and what activities are tolerated there. There are many cities around the world where some peri-urban lands and forests are publicly owned and are available for foraging, recreational, and even agricultural activities. In South Africa, these are referred to as urban commonages, and the foraging of firewood, medicinal plants, and wild foods is a common activity that is tolerated or encouraged as an important safety net for the urban poor [31,69]. However, the same activities are prohibited within the city limits. Although foraging is permitted on most municipal commonages in South Africa, there can be conflicts amongst different users, as not all land use activities are compatible with one another, and there may also be attempts at exclusion of the poor by the wealthy who seek to reserve commonage for grazing of their livestock $[69,70]$.

The harvesting of a variety of natural resources within urban landscapes is frequently disallowed by local bylaws [3]. The origins of such bylaws are typically hard to discern, but appear to be vested in fears relating to one or more of the following: (i) nature/biodiversity loss due to potentially damaging harvesting practices; (ii) unsightly damage to city assets or green infrastructure planted and maintained by the city; and (iii) public health. Each of these can be examined in both relative and absolute terms. On a relative basis, these concerns can generally be diluted, because other land transformation and land use pressures have far greater impacts on species and green spaces than urban foraging does. The fragmentation or diminishment of formal and informal green spaces for infrastructure development or waste dumping are major pressures in most cities of the world $[28,65,71]$ compared with which urban foraging is a relatively benign activity. Urban densification processes also take their toll on the extent of urban green space [5,72].

With respect to biodiversity loss in urban settings as a consequence of urban foraging, we are not aware of any information that explicitly interrogates this question, or any study reporting on urban respondents mentioning or lamenting such. The impacts of harvesting of natural resources in less transformed, rural, or protected landscapes are the subject of much research globally [73]. Those results are extremely varied, which reflects on the diversity of climates, landscapes, species, plant parts, and governance systems under which harvesting occurs [74]. The variability is also partially due to the different time-scale and research frameworks employed [75]. What is clear is that for rural and urban areas both, management guidelines need to be context-specific and designed in situ with all relevant stakeholders.

A second observation from our own studies and the limited literature is the common reference to significant levels of local ecological knowledge amongst urban foragers [3]. Whether they are foragers because of their knowledge of the local ecology and species or vice versa, a high level of local knowledge is typically regarded as a positive attribute in contributing to the ecological sustainability of resource harvesting [76,77]. Additionally, urban foraging may be undertaken in groups [39], which promotes the dissemination of such knowledge within the group and to newcomers. Gopal and Nagendra [19] describe the value of urban trees in providing shade and as places for social learning 
and knowledge sharing about a range of topics in the slums of Bangalore, which they postulate includes the uses and locations of locally harvested plants.

Any reduction in green spaces and species as a result of harvesting would potentially be a cause for concern to municipal authorities, because it can be perceived as a loss of investment. If local authorities have planted and/or maintained green areas or species that are subsequently harvested, it potentially represents some waste of the financial and human capital that went into establishing and maintaining those elements. However, one must also note that some resources are seasonal (e.g., fruits, mushrooms, flowers, seed pods), and some species can regrow after harvesting or re-establish annually from seed. The extent of removal from urban foraging is largely unknown, but in our experience, it is relatively small. However, authorities are likely to fear that if they allow a few people to forage, then others will follow suit, thereby increasing the likelihood of real damage to the resource. On the other hand, if urban foraging was permitted, and even encouraged, authorities could actively plan for it, as well as any possible increases in magnitude, by planting species (and more of them) used by local residents. For example, Grabbatin et al. [62] reported how natural sweetgrass stocks in coastal South Carolina declined due to coastal development, but subsequently were buoyed by the local authorities planting it along roadsides as an ornamental. In Grahamstown, South Africa, the municipality increasingly planted wild plum (Harpephyllum caffrum) along streets, thereby providing fruits for children and birds. Green spaces and street plantings are already provided, and thus it would just require reconsideration of the species, and in some instances, the spaces [3]. The planting of trees for urban firewood supplies is not uncommon in cities in sub-Saharan Africa such as Kigali, the rapidly growing capital of Rwanda [78].

Among planners and managers, and perhaps others, there are concerns around potential ill health effects associated with the growing, harvesting, and consumption of wild foods in urban settings. At the local scale, planners are concerned that some useful species may drop fruits, branches, or thorns that could harm pedestrians. For example, McLain et al. [3] describe how large-fruited species, such as apples, are prohibited as street trees in Seattle because of the fear of pedestrian injuries. At a more significant scale, Weeks et al. [79] posit that the most important concern is the heavy metal contamination of foods from urban pollution, especially from vehicular traffic emissions (something that is also likely to affect food grown in private gardens); however, this may be limited through the washing of harvested produce [80]. Another issue of concern might be residual traces of chemical poisons sprayed during vegetation management. These potential problems warrant investigation to dispel, mitigate, or affirm such concerns. Results of such research will be most meaningful if placed in the context of fresh produce available from other sources. However, in a future context, obviously the best option would be to drastically cut all forms of dangerous pollutions and vehicular emissions in urban areas.

\section{Conclusions and Future Directions}

Our thought piece is an examination of themes emerging from our own case studies and material from India, South Africa, Sweden, and the USA, supported with reference to other urban centres around the world. It demonstrates that urban foraging is a widespread practice that exhibits many similar characteristics across large-to-small cities in the developed and developing world. At the same time, urban foraging is characterised by social and ecological diversity in terms of who forages, their reasons for doing so, the benefits they receive, the knowledge required, the rights and governance systems, as well as the species and products harvested, the spaces used, and how they are managed.

Shifting biological and social access notwithstanding, urban foraging and the animal and plant materials and fungi obtained fulfil multiple functions for diverse individuals and communities. Urban foraging, inter alia:

(1). Provides frequently used subsistence resources [37,39,42],

(2). Acts as a coping strategy or safety net during times of misfortune, such as natural disasters or economic losses [81], 
(3). Offers savings of scarce cash income [20,21],

(4). Contributes to food and health security and sovereignty [4,11,21,37],

(5). Creates and sustains connections to nature and place $[11,62,66]$, and

(6). Supports identities and cultures [13,39,42,46,56,82].

Forager identities span social, cultural, and economic groups, and the benefits that foraging provides for them are many and often simultaneous. The relative importance of specific benefits may change through time in response to individual and collective circumstances, such as access to green spaces and species, the availability of employment or events including natural disasters, and armed conflict (Figure 2).

In any given city, dozens to hundreds of species appear to be harvested, including native and non-native species. These species are foraged across urban, suburban, and peri-urban landscapes; in other words, essentially any place where useful plant, fungi and animal resources can be found, including common, state, and privately owned lands. Foraging is a dispersed practice, with individual foragers sometimes travelling to multiple locations to obtain the species and experiences they seek. This diversity of systems, spaces, and species potentially counters the assumption voiced by Kujawska \& Łuczaj [24] that "it is well acknowledged that in urban centers people tend to use fewer wild edible plants than in rural areas due to limited access to such resources. The contemporary fashion for wild edible plants among city dwellers is usually limited to easily identifiable and readily available species [ ... ], with some specialized exceptions [ ... ]". In contrast, we see little evidence of "specialised exceptions", and more of unexplored ubiquity.

In addition to this diversity, urban foraging is socially, spatially, and temporally dynamic (Figure 2). Factors contributing to these dynamics include the intra- and international migration of humans and other species, as well as the constant reconfiguration of urban landscapes through processes including, but not limited to, development, densification, gentrification, privatisation, and abandonment. Foragers and foraging must, and do, adapt to these changing contexts. Often, they do so in ways that defy simple assumptions about circumstances such as economic status or length of tenure in place. The multigenerational and increasingly multiethnic nature of cities further emphasises the word diversity. Urban foraging does not mean the same to all groups, but does urban design and policy take sufficient cognisance of this? Is design sufficiently responsive to changing demographic profiles within cities, including the perceptions and needs of immigrants?

Despite the benefits to urban residents, most city authorities with whom we have interacted or learnt about through other research explicitly or implicitly prohibit urban foraging, although rules on the books and their interpretation may be ambiguous or rarely enforced. Public lands and private or institutional lands that function as de facto commons often are particularly important in terms of providing access to useful plant materials, fungi, and other resources. However, policy and management priorities for urban greenspaces generally favour recreational and aesthetic values. In urbanising environments, this may result in the closure of commons where foraging has previously taken place.

Although loss of access to foraging locations and resources frequently is observed, the novel ecologies of urban environments can provide forageable species not previously present in an area, and there are instances in which novel forms of negotiated access for foraging arise. Further, some cities have an evidenced interest in adopting policies to accommodate foraging (e.g., Seattle, WA, US), and there are civic efforts to develop food forests in communities in North America and Europe, sometimes in partnership with city governments.

Urban greenspace managers and policymakers may face aesthetic, ecological, and public health concerns as they consider whether to accommodate foraging in cities. Recent literature suggests that the risks of exposure to contaminants from consuming foraged plant materials and fungi from urban spaces may be minimal to non-existent for selected species and locations, although further research is warranted [80]. While there is a lack of data on the ecological effects of foraging on urban biodiversity and local species abundance, until such a time such data are available, research conducted in rural 
environments may be indicative of likely outcomes. This scholarship suggests that the outcomes for species populations are conditioned by the particulars of harvest. Further, foragers' ecological knowledge and the benefits they derive from urban nature may act as incentives to steward the species and landscapes they use. Finally, the relative impact of foraging is dwarfed by land use and land cover changes that are part of urbanisation processes.

Urban nature is a source of ecosystem services that benefit city economies and residents' well-being. To date, most of the scholarship and policy research on urban ecosystem services has focused on regulating and supporting functions, an emphasis that results in undervaluing urban nature's full contributions to human well-being. Future research to rectify this shortfall will address basic aspects of foraging, as well as the contexts within which it occurs. These contexts include, but are not limited to: potential exposure to contaminants from the consumption of urban foraged plants and fungi, and best practices for mitigating any risks; factors influencing the sustainability of urban foraging; opportunities to design urban greenspaces and governance structures to enhance provisioning and cultural ecosystem services from foraging, and aspects of environmental justice in terms of who has access to what, and how urbanisation dynamics may affect the equity related to greenspaces and the resources (material and immaterial) that they contain (Figure 2).

Beyond the practical ways foraging research can contribute to understandings of ecosystem services, research specifically on urban foraging remains in its early stages. The synthesis presented here suggests key ways that future empirical research can address important questions about this ubiquitous practice. Figure 2 depicts the social-ecological systems in which foraging operates, highlighting the ways we see urban ecological contexts—or cities as novel biomes [47] —as shaped first by social-economic contexts, and secondarily by bio-physical context (which are also deliberately or unconsciously modified by the social-economic dynamics). Within the social and ecological settings at the local scale, foraging is comprised of and influenced by diverse actors and the specific practices they undertake in relation to an array of sites and species. Together, the interactions between people and species and the practices and sites that link the two characterise urban foraging systems.

As argued throughout this paper, urban foraging systems are dynamic and influenced by a wide variety of drivers of change, which shape urban foraging systems at multiple scales and levels of interaction. To foster a better understanding of dynamic urban foraging systems around the planet, we encourage scholars to consider the characteristics of individual and group foraging practices and the species involved, including the changing political, economic, and ecological changes that shape these practices. Future research should examine past and current motivations for foraging by individuals and communities; how foraged materials have contributed to and underpin identities, cultures, and health and well-being; and the ways that foragers negotiate access to the species they forage and the locations that support these species (Figure 2).

Paying attention to the interactions between people, species, spaces, and governance systems involved, including the variation in responses by foragers and the flexibility of their practices, can reveal the dynamism of urban foraging. Here, changes in conditions of ecological availability and social access in relation to issues of equity may be critical, as well as the evolving pathways of knowledge transmission that perpetuate foraging. Critically, research should consider what past, current, and new steps foragers must take to adapt their practices to new locations and species. Further, scholars will need to be attentive to the spaces that are used by foragers, and why these spaces in particular support the harvest of particular species and even distinctive uses, where others do not. Particular emphasis on differences in the seasonal mix of species as well as differences in species distribution across a city and its greenspace types may be critical to these endeavors (Figure 2).

As a complex and dynamic activity that contributes to urban livability, individual well-being, and socio-environmental equity in many ways, there are many questions that remain unanswered (Figure 2). Additionally, there is the need for these questions to be examined in a wide variety of geographic, social, and ecological settings to enable the meta-analysis of patterns and processes. The complexity of urban foraging also cries out for (1) the deployment of a wider range of existing 
and new methodological approaches, including actor analysis, institutional analysis, and GIS; (2) the linking of research with action via transdisciplinarity, social learning, and citizen science; (3) linking research with education through involving of learners and incorporating urban foraging information into formal educational curricula and informal courses and activities of interested non-governmental and community-based organisations; and (4) a higher degree of involvement of city planners and managers at different levels in research endeavours.

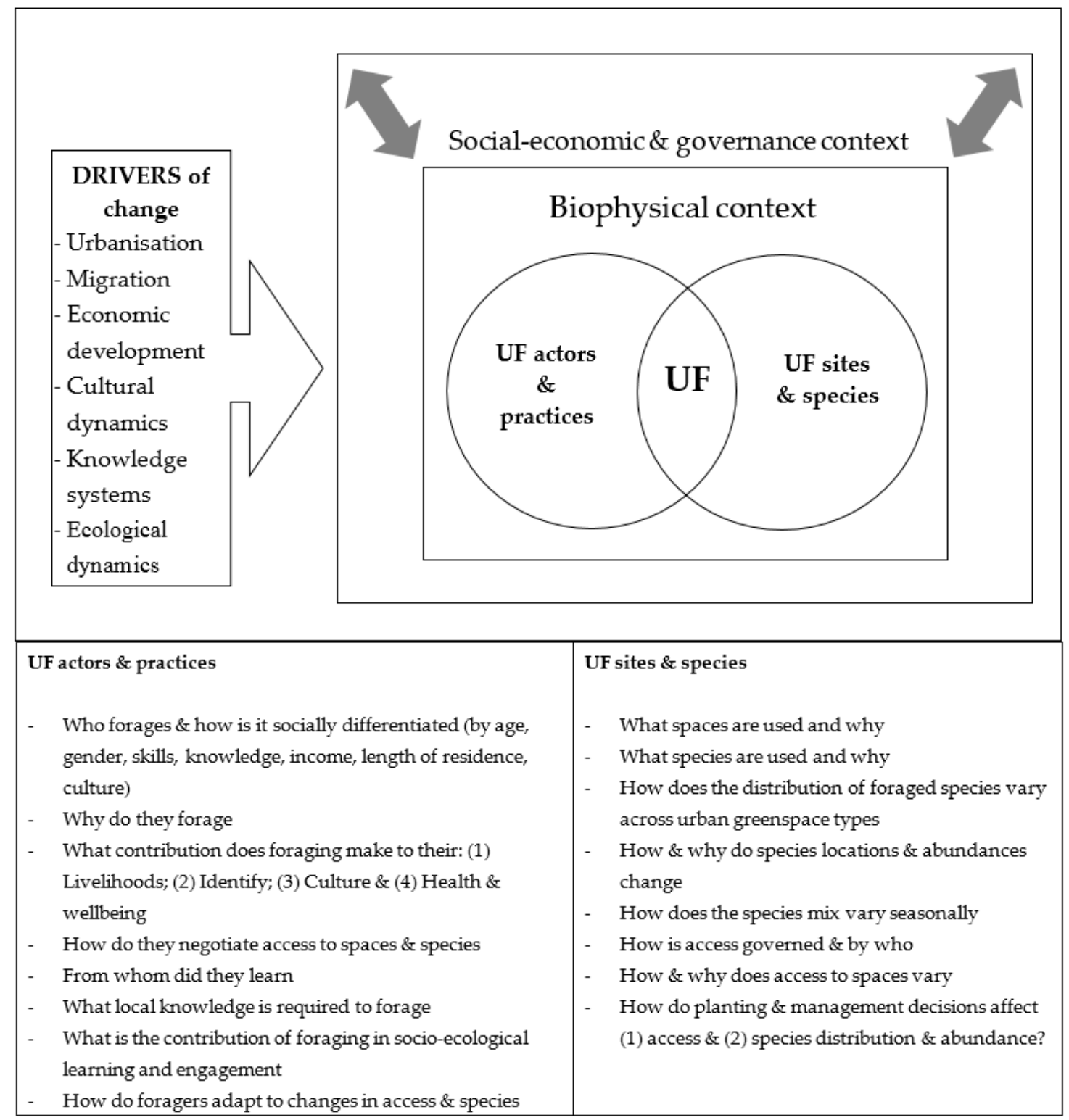

Figure 2. The urban foraging system shaped by the local biophysical and social-economic contexts, which in turn are shaped by external drivers of change in time.

Assessing the full range and values of the ecosystem services provided by urban nature will require understanding urban foraging, including foraged species and their uses, and foragers and their practices, beliefs and knowledge. The formulation of policy, design, and management strategies in support of the provisioning and cultural ecosystem services provided by urban foraging will benefit from understanding the common characteristics of foraging in cities worldwide, but will also require comprehension of the specific context in which they are to be implemented. 
Acknowledgments: The contribution by A.D. was supported by The Swedish Research Council Formas. H.N.'s contribution was funded by a research grant from Azim Premji University. C.S.'s contribution was sponsored by the South African Research Chairs Initiative of the Dept of Science and Technology and the National Research Foundation of South Africa (any opinion, finding, conclusion or recommendation expressed in this material is that of the authors and the N.R.F. does not accept any liability in this regard). We are grateful for comments on an earlier draft of this paper by Paul Gobster and we additionally appreciated the constructive comments from three anonymous reviewers.

Author Contributions: C.S. and P.H. conceived of the paper and all authors then contributed to writing it.

Conflicts of Interest: The authors declare that there are no conflicts of interest.

\section{References}

1. Simons, A.; Maitri, M. The food remains from Casselden Place, Melbourne, Australia. Int. J. Hist. Arch. 2006, 10, 349-365. [CrossRef]

2. Pickett, S.T.A.; Boone, C.G.; McGrath, B.P.; Cadenasso, M.L.; Childers, D.L.; Ogden, L.A.; McHale, M.; Grove, M.J. Ecological science and transformation to the sustainable city. Cities 2013, 32, 510-520. [CrossRef]

3. McLain, R.; MacFarland, K.; Brody, L.; Buttolph, L.B.; Hebert, J.; Hurley, P.; Gabriel, N.; Emery, M.; Poe, M.; Charnley, S.; et al. Gathering in the City: An Annotated Bibliography on Urban Non-Timber Forest Products Gathering; Pacific Northwest Research Station: Corvallis, OR, USA, 2012.

4. Mollee, E.; Pouliot, M.; McDonald, M.A. Into the urban wild: Collection of wild urban plants for food and medicine in Kampala, Uganda. Land Use Policy 2017, 63, 67-77. [CrossRef]

5. Haaland, C.; van den Konijnendijk Bosch, C. Challenges and strategies for urban green-space planning in cities undergoing densification: A review. Urban For. Urban Green. 2015, 14, 760-771. [CrossRef]

6. Russo, A.; Escobedo, F.J.; Cirella, G.T.; Zerbe, S. Edible green infrastructure: An approach and review of provisioning ecosystem services and disservices in urban environments. Agric. Ecosyst. Environ. 2017, 242, 53-66. [CrossRef]

7. Rupprecht, C.D.; Byrne, J.A.; Garden, J.G.; Hero, J.-M. Informal urban green space: A trilingual systematic review of its role for biodiversity and trends in the literature. Urban For. Urban Green. 2015, 14, 883-908. [CrossRef]

8. Tzoulas, K.; Korpela, K.; Venn, S.; Yli-Pelkonen, V.; Kázmierczak, A.; Niemela, J.; James, P. Promoting ecosystem and human health in urban areas using Green Infrastructure: A literature review. Landsc. Urban Plan. 2007, 81, 167-178. [CrossRef]

9. Shanahan, D.F.; Lin, B.B.; Bush, R.; Gaston, K.J.; Dean, J.H.; Barber, E.; Fuller, R.A. Toward improved public health outcomes from urban nature. Am. J. Public Health 2015, 105, 470-477. [CrossRef] [PubMed]

10. McPhearson, T.; Pickett, S.T.A.; Grimm, N.B.; Niemelä, J.; Alberti, M.; Elmqvist, T.; Weber, C.; Haase, D.; Breuste, J.; Qureshi, S. Advancing urban ecology toward a science of cities. BioScience 2016. [CrossRef]

11. Plieninger, T.; Bieling, C.; Fagerholm, N.; Byg, A.; Hartel, T.; Hurley, P.; López-Santiago, C.A.; Nagabhatla, N.; Oteros-Rozas, E.; Raymond, C.M.; et al. The role of cultural ecosystem services in landscape management and planning. Curr. Opin. Environ. Sustain. 2015, 14, 28-33. [CrossRef]

12. Poe, M.R.; McLain, R.J.; Emery, M.; Hurley, P.T. Urban forest justice and the rights to wild foods, medicines, and materials in the city. Hum. Ecol. 2013, 41, 409-422. [CrossRef]

13. McLain, R.J.; Hurley, P.T.; Emery, M.R.; Poe, M.R. Gathering "wild" food in the city: Rethinking the role of foraging in urban ecosystem planning and management. Local Environ. 2014, 19, 220-240. [CrossRef]

14. Svizzero, S. Foraging wild resources: Evolving goals of an ubiquitous human behavior. Anthropology $2016,4$. [CrossRef]

15. Saastamoinen, O. Forest policies, access rights and non-wood forest products in northern Europe. Unasylva 1999, 50, 20-26.

16. Cotriou, L. Valuing the non-timber forest products in the Mediterranean region. Ecol. Econ. 2007, 63, 768-775.

17. Stryamets, N.; Elbakidze, M.; Ceuterick, M.; Angelstam, P.; Axelsson, R. From economic survival to recreation: Contemporary uses of wild food and medicine in rural Sweden, Ukraine and NW Russia. J. Ethnobiol. Ethnomed. 2015, 11, 1-18. [CrossRef] [PubMed]

18. Dahlberg, A.C.; Trygger, S.B. Indigenous medicine and primary health care: The importance of lay knowledge and use of medicinal plants in rural South Africa. Hum. Ecol. 2009, 37, 79-94. [CrossRef] 
19. Gopal, D.; Nagendra, H. Vegetation in Bangalore's slums: Boosting livelihoods, well-being and social capital. Sustainability 2014, 6, 2459-2473. [CrossRef]

20. Kaoma, H.; Shackleton, C.M. The direct-use value of urban tree non-timber forest products to household income in poorer suburbs in South African towns. For. Policy Econ. 2015, 61, 104-112. [CrossRef]

21. Schlesinger, J.; Drescher, A.; Shackleton, C.M. Socio-spatial dynamics in the use of wild natural resources: Evidence from six rapidly growing medium-sized cities in Africa. Appl. Geogr. 2015, 56, 107-115. [CrossRef]

22. Kangas, K.; Markkanen, P. Factors affecting participation in wild berry picking by rural and urban dwellers. Silva Fenn. 2001, 35, 487-495. [CrossRef]

23. Emery, M.; Martin, S.; Dyke, A. Wild harvests from Scottish woodlands. In Social, Cultural and Economic Values of Contemporary Non-Timber Forest Products; Forestry Commission: Edinburgh, UK, 2003.

24. Kujawska, M.; Luczaj, L. Wild edible plants used by the Polish community in Misiones, Argentina. Hum. Ecol. 2015, 43, 855-869. [CrossRef] [PubMed]

25. Konijnendijk, C. The Forest and the City: The Cultural Landscape of Urban Woodland; Springer: New York, NY, USA, 2008; 245p.

26. McLain, R.; Poe, M.; Hurley, P.T.; Lecompte-Mastenbrook, J.; Emery, M.R. Producing edible landscapes in Seattle's urban forest. Urban For. Urban Green. 2012, 11, 187-194. [CrossRef]

27. Kaoma, H.; Shackleton, C.M. Collection of urban tree products by households in poorer residential areas of three South African towns. Urban For. Urban Green. 2014, 13, 244-252. [CrossRef]

28. Paul, S.; Nagendra, H. Vegetation change and fragmentation in the mega-city of Delhi: Mapping 25 years of change. Appl. Geogr. 2015, 58, 153-166. [CrossRef]

29. Edelman, I. Tradition, Kultur och Kunskapsöverföring: En Studie om Användningen och Betydelsen av Skogens Ätliga Resurser Bland Personer med Polsk Bakgrund Boende I Stockholmsregionen. [Tradition, Culture and Knowledge Transfer. A Study on the Use and Meaning of the Edible Produce from the Forest among People with Polish Background Living in the Stockholm Region.]. Master's Thesis, Stockholm University, Stockholm, Sweden, 2013.

30. Terada, T.; Yokohari, M.; Bolthouse, J.; Tanaka, N. Refueling Satoyama woodlands restoration in Japan: Enhancing restoration practice and experiences through woodfuel utilisation. Nat. Cult. 2010, 5, 251-276. [CrossRef]

31. Davenport, N.A.; Shackleton, C.M.; Gambiza, J. The direct use value of municipal commonage goods and services to urban households in the Eastern Cape, South Africa. Land Use Policy 2012, 29, 548-557. [CrossRef]

32. Hurley, P.; Grabbatin, B.; Halfacre, A.; Goetcheus, C. Gathering, buying, and growing grass: Urbanization and social networking in the sweetgrass basket-making industry of lowcountry South Carolina. In African Ethnobotany in the Americas; Voeks, R., Rashford, J., Eds.; Springer: New York, NY, USA, 2012; pp. 153-174.

33. Poe, M.R.; LeCompte, J.; McLain, R.; Hurley, P. Urban foraging and the relational ecologies of belonging. Soc. Cult. Geogr. 2014, 15, 901-919. [CrossRef]

34. Murwendo, T. Improving urban livelihoods at household level through sustainable utilisation of peri-urban forests in Masvingo City. J. Sustain. Dev. Afr. 2011, 13, 299-313.

35. Nkambwe, M.; Sekhwela, M.B. Utilization characteristics and importance of woody biomass resources on the rural-urban fringe in Botswana. Environ. Manag. 2006, 37, 281-296. [CrossRef] [PubMed]

36. Wendel, H.E.W.; Zarger, R.K.; Mihelcic, J.R. Accessibility and usability: Green space preferences, perceptions, and barriers in a rapidly urbanizing city in Latin America. Landsc. Urban Plan. 2012, 107, 272-282. [CrossRef]

37. Unnikrishnan, H.; Nagendra, H. Privatization of the commons: Impact on ecosystem services in Bangalore's lakes. Urban Ecosyst. 2015, 18, 613-632. [CrossRef]

38. Jahnige, P. The hidden bounty of the urban forest. In Nontimber Forest Products in the United States; Jones, E.T., McLain, R.J., Weigand, J., Eds.; University Press of Kansas: Lawrence, Kansas, 2002; pp. 96-101.

39. Hurley, P.T.; Emery, M.R.; Mclain, R.; Poe, M.; Grabbatin, B.; Goetcheus, C.L. Whose urban forest? The political ecology of foraging urban nontimber forest products. In Sustainability in the Global City: Myth and Practice; Isenhour, C., McDonagh, G., Checker, M., Eds.; Cambridge: New York, NY, USA, 2015; pp. 187-212.

40. Nagendra, H. Nature in the City: Bengaluru in the Past, Present and Future; Oxford University Press: New Delhi, India, 2016.

41. Wehi, P.M.; Wehi, W.L. Traditional plant harvesting in contemporary fragmented and urban landscapes. Conserv. Biol. 2010, 24, 594-604. [CrossRef] [PubMed] 
42. Shackleton, S.E.; Chinyimba, A.; Hebinck, P.; Shackleton, C.; Kaoma, H. Multiple benefits and values of trees in urban landscapes in two towns in northern South Africa. Landsc. Urban Plan. 2015, 136, 76-86. [CrossRef]

43. Gianotti, A.S.; Hurley, P. Gathering plants and fungi along the urban-rural gradient: Uncovering differences in the attitudes and practices among urban, suburban, and rural landowners. Land Use Policy 2016, 57, 555-563. [CrossRef]

44. Palliwoda, J.; Kowarik, I.; von der Lippe, M. Human-biodiversity interactions in urban parks: The species level matters. Landsc. Urban Plan. 2017, 157, 394-406. [CrossRef]

45. Robbins, P.; Emery, M.; Rice, J.L. Gathering in Thoreau's backyard: Nontimber forest product harvesting as practice. Area 2008, 40, 265-277. [CrossRef]

46. Emery, M.R.; Hurley, P.T. Ethnobiology in the city: Embracing the urban ecological moment. J. Ethnobiol. 2016, 36, 807-819. [CrossRef]

47. Pincetl, S. Cities as novel biomes: Recognising urban ecosystem services as anthropogenic. Front. Ecol. Evol. 2015. [CrossRef]

48. Lanza, K.; Stone, B. Climate adaptation in cities: What trees are suitable for urban heat management? Landsc. Urban Plan. 2016, 153, 74-82. [CrossRef]

49. D'Souza, R.; Nagendra, H. Changes in public commons as a consequence of urbanization: The Agara lake in Bangalore, India. Environ. Manag. 2011, 47, 840-850. [CrossRef] [PubMed]

50. Hurley, P.; Halfacre, A.; Levine, N.; Burke, M. Finding a "disappearing" nontimber forest resource: Using grounded visualization to explore urbanization impacts on sweetgrass basket making in Greater Mt. Pleasant, SC. Prof. Geogr. 2008, 60, 556-578. [CrossRef]

51. Clark, K.H.; Nicholas, K.A. Introducing urban food forestry: A multifunctional approach to increase food security and provide ecosystem services. Landsc. Ecol. 2013, 28, 1649-1669. [CrossRef]

52. Emery, M.; Ginger, C.; Newman, S.; Giammusso, M.R.B. Special Forest Products in Context: Gatherers and Gathering in the Eastern United States; General Technical Report, NE-306; U.S. Department of Agriculture, Forest Service, Northeastern Research Station: Newtown Square, PA, USA, 2003.

53. Redzic, S. Use of wild and semi-wild edible plants in nutrition and survival of people in 1430 days of siege of Sarajevo during the war in Bosnia and Herzegovina (1992-1995). Coll. Antropol. 2010, 34, 551-570. [PubMed]

54. Jensen, E.L.; Ouis, P. Contested construction of nature for city fringe outdoor recreation in southern Sweden: The Arrie case. Urban For. Urban Green. 2008, 7, 171-182. [CrossRef]

55. Poteete, A.R.; Welch, D. Institutional development in the face of complexity: Developing rules for managing forest resources. Hum. Ecol. 2004, 32, 279-311. [CrossRef]

56. Ouis, P.; Jensen, L.E. "I brought a hazelnut from Macedonia": Cultural and biological diversity in a globalizing world. In Transcending Boundaries: Environmental Histories from the Öresund Region; Malmö University: Malmö, Sweden, 2009; pp. 127-141.

57. Larsson, L. An Environmental Justice Perspective on Access to Outdoor Recreation: Changes in Use, Value and Planning of Hokarangen's Recreational Landscape. Master's Thesis, Stockholm University, Stockholm, Sweden, 2014.

58. Ward, C.D.; Shackleton, C.M. Natural resource use, incomes and poverty along the rural-urban continuum of two medium-sized South African towns. World Dev. 2016, 78, 80-93. [CrossRef]

59. Taylor, L.E.; Hurley, P.T. Introduction: The broad contours of exurban landscape change. In A Comparative Political Ecology of Exurbia: Planning, Environmental Management, and Landscape Change; Taylor, L.E., Hurley, P.T., Eds.; Springer: Berlin, Germany, 2016; pp. 1-29.

60. Hedblom, M.; Andersson, E.; Borgström, S. Flexible land-use and undefined governance: From treats to potentials in peri-urban landscape planning. Land Use Policy 2017, 63, 523-527. [CrossRef]

61. Halfacre, A.; Hurley, P.T.; Grabbatin, B. Sewing environmental justice into African-American sweetgrass basket-making in the South Carolina Lowcountry. Southeast. Geogr. 2010, 50, 147-168. [CrossRef]

62. Grabbattin, B.; Hurley, P.T.; Halfacre, A. "I still have the old tradition". The co-production of sweetgrass basketry and coastal development. Geoforum 2011, 42, 638-649. [CrossRef]

63. Ginger, C.; Emery, M.R.; Baumflek, M.; Punam, D. Access to natural resources on private property: Factors beyond right of entry. Soc. Nat. Res. 2012, 25, 700-715. [CrossRef]

64. Petersen, L.M.; Moll, E.J.; Collins, R.; Hockings, M.T. Development of a compendium of local, wild-harvested species used in the informal economy trade, Cape Town, South Africa. Ecol. Soc. 2012, 17. [CrossRef] 
65. Nagendra, H.; Gopal, D. Tree diversity, distribution, history and change in urban parks: Studies in Bangalore, India. Urban Ecosyst. 2011, 14, 211-223. [CrossRef]

66. Unnikrishnan, H.; Manjunatha, B.; Nagendra, H. Contested urban commons: Mapping the transition of a lake to a sports stadium in Bangalore. Int. J. Commons 2016, 10, 263-293.

67. Unnikrishnan, H.; Mundoli, S.; Manjunatha, B.; Nagendra, H. Down the drain: The tragedy of the disappearing urban commons of Bengaluru. South Asian J. Water Stud. 2016, 5, 7-11.

68. Hopf, T. Limits to freedom-Debate on restricting free access to landscapes in Sweden is gaining momentum. Nat. Landsch. 2012, 87, 451-454.

69. Martins, C. The contribution of municipal commonage to land reform in South Africa: A case study of the Eastern Cape. In Reforming Land and Resource Use in South Africa: Impact on Livelihoods; Hebinck, P., Shackleton, C.M., Eds.; Routledge: London, UK, 2015; pp. 254-274.

70. Davenport, N.A.; Gambiza, J. Municipal commonage policy and livestock owners: Findings from the Eastern Cape. Land Use Policy 2008, 26, 513-520. [CrossRef]

71. Zhou, X.; Wang, Y.-C. Spatial-temporal dynamics of urban green space in response to rapid urbanization and greening policies. Landsc. Urban Plan. 2011, 100, 268-277. [CrossRef]

72. Pauleit, S. Perspectives on urban green space in Europe. Built Environ. 2003, 29, 89-93. [CrossRef]

73. Stanley, D.; Voeks, R.; Short, L. Is non-timber forest product harvest sustainable in the less developed world? A systematic review of the recent economic and ecological literature. Ethnobiol. Conserv. 2012, 1. Available online: http:/ / ethnobioconservation.com/index.php/ebc/article/view/19/20 (accessed on 17 October 2017). [CrossRef]

74. Ticktin, T. The ecological sustainability of non-timber forest product harvest: Principles and methods. In Ecological Sustainability for Non-Timber Forest Products; Dynamics and Case Studies of Harvesting; Shackleton, C.M., Ticktin, T., Pandey, A., Eds.; Earthscan: London, UK, 2015; pp. 31-52.

75. Dahlberg, A.C. The importance of environmental history in evaluating sustainability of non-timber forest product harvesting systems. In Ecological Sustainability for Non-Timber Forest Products; Dynamics and Case Studies of Harvesting; Shackleton, C.M., Ticktin, T., Pandey, A., Eds.; Earthscan: London, UK, 2015; pp. 53-70.

76. Shaankar, R.U.; Ganeshaiah, K.N.; Krishnan, S.; Ramya, R.; Meera, C.; Aravind, N.A.; Kumar, A.; Rao, D.; Vanaraj, G.; Ramachandra, J.; et al. Livelihood gains and ecological costs of non-timber forest product dependence: Assessing the roles of dependence, ecological knowledge and market structure in three contrasting human and ecological settings in south India. Environ. Conserv. 2004, 31, 242-253. [CrossRef]

77. Schmidt, I.B.; Figueiredo, I.B.; Ticktin, T. Sustainability of golden grass flower stalk harvesting in the Brazilian savanna. In Ecological Sustainability for Non-Timber Forest Products: Dynamics and Case Studies of Harvesting; Shackleton, C.M., Pandey, A.K., Ticktin, T., Eds.; Earthscan: London, UK, 2015; pp. 199-214.

78. Seburanga, J.L.; Kaplin, B.A.; Zhang, Q.-X.; Gatesire, T. Amenity trees and green space structure in urban settlements of Kigali, Rwanda. Urban For. Urban Green. 2014, 13, 84-93. [CrossRef]

79. Weeks, C.A.; Croasdale, M.; Osborne, M.A.; Hewitt, L.; Miller, P.F.; Robb, P.; Baxter, M.J.; Warriss, P.D.; Knowles, T.G. Multi-element survey of wild edible fungi and blackberries in the UK. Food Addit. Contam. 2006, 23, 140-147. [CrossRef] [PubMed]

80. Von Hoffen, L.P.; Samuel, I. Orchards for edible cities: Cadmium and lead content in nuts, berries, pome and stone fruits harvested within the inner city neighborhoods in Berlin, Germany. Ecotoxicol. Environ. Saf. 2014, 101, 233-239. [CrossRef] [PubMed]

81. Shackleton, C.M.; Blair, A.; De Lacy, P.; Kaoma, H.; Mugwagwa, N.; Dalu, M.T.; Walton, W. How important is green infrastructure in small and medium-sized towns? Lessons from South Africa. Landsc. Urban Plan. 2017. [CrossRef]

82. Cocks, M.; Alexander, J.; Mogano, L.; Vetter, S. Ways of belonging: Meanings of "nature" among Xhosa-speaking township residents in South Africa. J. Ethnobiol. 2016, 36, 820-841. [CrossRef]

(C) 2017 by the authors. Licensee MDPI, Basel, Switzerland. This article is an open access article distributed under the terms and conditions of the Creative Commons Attribution (CC BY) license (http:/ / creativecommons.org/licenses/by/4.0/). 